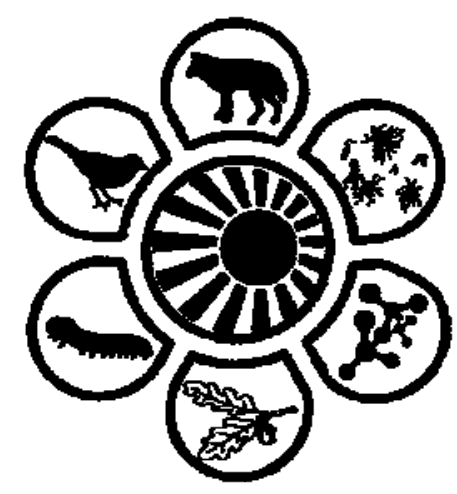

Вісник Дніпропетровського університету. Біологія, екологія.

Vìsnik Dnìpropetrovs'kogo unìversitetu. Seriâ Bìologiâ, ekologiâ

Visnyk of Dnipropetrovsk University. Biology, ecology.

Vìsn. Dnìpropetr. Unìv. Ser. Bìol. Ekol. 2015. 23(2), 221-224.

doi: $10.15421 / 011532$

ISSN 2310-0842 print

ISSN 2312-301X online

www.ecology.dp.ua

УДК [581.1:582.926.2]:661.162.65

\title{
Вплив синтетичних стимуляторів росту на морфофізіологічні характеристики та біологічну продуктивність культури картоплі
}

\author{
В.В. Рогач, T.I. Рогач \\ Вінницький державний педагогічний університет імені Михайла Коџююбинського, Вінниия, Украӥна
}

\begin{abstract}
Досліджено вплив синтетичних стимуляторів росту рослин на ріст, розвиток і продуктивність культури картоплі. Застосування гіберелової кислоти, 1-нафтилоцтової кислоти та 6-бензиламінопурину - високоефективний засіб регуляції морфогенезу та продуктивності картоплі. Лінійні розміри рослин картоплі та маси сухої та сирої речовини цілої рослини збільшувалися лише за умов застосування гіберелової кислоти. Інші регулятори росту показників достовірно не змінювали. За дії гіберелової кислоти та 6-бензиламінопурину збільшувалася кількість листків на рослині, маса сирої та сухої речовини листя, що $є$ однією 3 основних передумов посилення фотосинтетичної активності рослини. Усі три стимулятори росту збільшували площу листкової поверхні. Гіберелова та 1-нафтилоцтова кислоти зумовлювали потовщення хлоренхіми та зростання об'єму клітин стовпчастої паренхіми. Наслідком збільшення площі листя та розростання мезофілу стало підвищення листкового індексу та питомої поверхневої щільності листків. Зміни фітометричних і мезоструктурних показників листків та збільшення вмісту суми хлорофілів за дії регуляторів росту сприяли посиленню фотосинтетичної активності листкового апарату, наслідком чого було підвищення показника чистої продуктивності фотосинтезу та зростання урожайності культури. Найефективнішим було застосування гіберелової кислоти та 6-бензиламінопурину.
\end{abstract}

Ключові слова: картопля європейська; Solanum tuberosum; морфогенез; активатори росту; урожайність

\section{Influence of synthetic growth stimulators on morphological and physiological characteristics and biological productivity of potato culture}

\author{
V.V. Rogach, T.I. Rogach \\ Vinnytsya State Pedagogical University named after Mykhailo Kotsubinskyi, Vinnytsya, Ukraine
}

Effect of the synthetic plant growth stimulators on growth, development and productivity of potato crops has been studied. It is established that the use of gibberellic acid, 1-naphthylacetic acid and 6-benzylaminopurine is highly effective means for regulating morphogenesis and productivity of potato. It is found that the linear dimensions of potato and weight of raw and dry matter of the whole plant increase only upon applying gibberellic acid. Other growth regulators have not changed the indexes significantly. The number of leaves per plant, weight of raw and dry matter of leaves increased under the influence of gibberellic acid and 6-benzylaminopurine, that was one of the main prerequisites to strengthen the photosynthetic activity of plants. All growth stimulators increased the leaf area. Gibberellic acid and 1-naphthylacetic acid reasoned the thickening of the chlorenchyma and growth of columnar cells of the parenchyma. Increase in leaf area and proliferation of mesophyll resulted in the increase of the leaf index and specific surface density of the leaf. Changes of phytometric and mezo-structure indexes of leaves and increase in the amount of chlorophyll under the influence of growth regulators contributed to intensification of photosynthetic activity of the leaf apparatus, and its consequence was the increase in net photosynthetic productivity and crop yields. The use of gibberellic acid and 6-benzylaminopurine proved to be the most effective.

Keywords: European potato; Solanum tuberosum; morphogenesis; growth stimulators; productivity

Вінницький державний педагогічний університет імені Михайла Кочюбинського, вул. Острожсського, 32, Вінниия, 21000, Украйна Vinnytsya State Pedagogical University named after Mykhailo Kotsubinskyi, Ostrozhskogo Str., 32, Vinnytsya, 21000, Ukraine Tel.:+38-098-594-48-32.E-mail: rogachv@ukr.net 


\section{Вступ}

Зростаючі потреби сучасного аграрного виробництва визначають необхідність пошуку нових шляхів і способів підвищення продуктивності сільськогосподарських культур та якості їх продукції. Важливим компонентом сучасних технологій рослинництва є регулятори росту (Komarova, 1998; Henselová, 1998; Romaniuk et al., 1998; Zrůst and Henselová, 1998; Chirag et al., 2007; Bobyliov et al., 2014). Інтерес до даної групи сполук зумовлений широким спектром їх дії на рослини, можливістю спрямовано регулювати окремі етапи онтогенезу з метою мобілізації потенційних можливостей рослинного організму та ефективнішої реалізації генетичної програми (Khan and Samiullah, 1998; Vizárová and Macháčková, 2001; Malinauskaitè and Jakienè, 2005). Найбільш застосовуваною групою регуляторів росту є стимулятори - нативні фітогормони та їх синтетичні аналоги (Laichicxi et al., 2002; Gavelienè et al., 2007). За допомогою цих сполук можна впливати на інтенсивність і спрямованість фізіологічних процесів у рослинному організмі (Xinping et al., 2002; Angela, 2004; Povh and Ono, 2006; Fauate et al., 2007).

Продуктивність рослин великою мірою визначається стратегією перерозподілу асимілятів, співвідношенням процесів росту та фотосинтезу, між якими встановлюється динамічний стан із постійною корекцією величини донорно-акцепторних відносин залежно від різноманітних зовнішніх впливів (Junying et al., 2002; Xinping et al., 2002). Саме нативні гормони та їх синтетичні аналоги можуть спрямовано регулювати фізіолого-біохімічні процеси у рослині та спрямовувати потоки асимілятів до господарсько цінних тканин i органів (Khan and Samiullah, 1998; Vizárová and Macháčková, 2001; Povh and Ono, 2006; Gavelienè et al., 2007).

У зв'язку із цим мета нашого дослідження - виявити вплив синтетичних аналогів основних стимулювальних гормонів (ауксинів, цитокінінів та гіберелінів) на ріст, розвиток і продуктивність картоплі.

\section{Матеріал і методи досліджень}

Польові дрібноділянкові досліди закладали на землях СФГ «Бержан П.Г.», с. Горбанівка Вінницького району Вінницької області у вегетаційні періоди 2013 і 2014 років. Посадку картоплі середньораннього сорту Санте проводили 18.04.2013 та 03.05.2014 р. за схемою $70 \times 30$ см. Площа ділянок - 33 м², повторність досліду - п'ятиразова. Рослини обробляли вранці за допомогою ранцевого оприскувача ОП-2 до повного змочування листків 0,005\% розчином гіберелової кислоти (ГК3), 0,005\% розчином 1-нафтилоцтової кислоти (1-НОК) і 0,005\% розчином 6-бензиламінопурину (6-БАП) у фазу бутонізації 14.06.2013 та 17.06.2014 р. Контрольні рослини обприскували водопровідною водою.

Фітометричні показники (висоту рослин, масу сухої та сирої речовини рослини та листя, площу листків) визначали на 20 рослинах (Bala et al., 2013). Відбирання матеріалів для вивчення мезоструктурної організації листка проводили у фазу початку бульбоутворення. Мезоструктуру листків дослідних рослин вивчали на фіксованому матеріалі. Для його консервації застосовували суміш рівних частин етилового спирту, гліцерину, води 3 додаванням 1\% формаліну. Визначення розмірів клітин, товщини їх хлоренхіми здійснювали за допомогою мікроскопа Мікмед-1 та окулярного мікрометра MOB-1-15x. Для мезоструктурного аналізу відбирали листки середнього ярусу, анатомічні показники стебла визначали також у середній його частині (Bala et al., 2013).

Визначення вмісту хлорофілів проводили у свіжому матеріалі спектрофотометричним методом на спектрофотометрі СФ-18 (Bala et al., 2013). Протягом вегетації визначали чисту продуктивність фотосинтезу, листковий індекс як площу всіх листків на одиницю поверхні грунту (Bala et al., 2013). Урожайність визначали методом підрахунку та зважування з кожної ділянки окремо.

Результати досліджень обробляли статистично за допомогою комп'ютерної програми Statistica 6.0. Застосовували однофакторний дисперсійний аналіз (відмінності між середніми значеннями обчислювали за критерієм Стьюдента, їх вважали вірогідними за $\mathrm{P}<0,05$ (Van Emden, 2008). У таблиці та на рисунку наведено середньоарифметичні значення та їх стандартні похибки.

\section{Результати та їх обговорення}

За результатами наших досліджень установлено, що синтетичні стимулятори росту та розвитку рослин 1-нафтилоцтова, гіберелова кислоти та 6-бензиламінопурин зумовили зміни морфогенезу та продуктивності рослин картоплі сорту Санте (табл.). Зокрема, встановлено, що застосування гіберелової кислоти зумовлювало збільшення лінійних розмірів рослин на кінець вегетації в середньому на 20\% по роках досліджень (Khan and Samiullah, 1998; Fauate et al., 2007). У випадку застосування інших стимуляторів росту висота рослин достовірно не змінювалася. Одночасно за дії гіберелінового стимулятора достовірно зростала маса сирої та сухої речовини цілої рослини, тоді як за умов обробки іншими препаратами спостерігали лише тенденцію до збільшення згаданих показників (Khan and Samiullah, 1998; Fauate et al., 2007).

Застосування рістстимулювальних препаратів викликало зміни у листковому апараті рослин картоплі. Гібереліновий та цитокініновий препарати зумовлювали достовірне збільшення кількості листків на рослині, маси сирої та сухої речовини листків, що $є$ типовою реакцією рослинного організму на дію стимуляторів росту та знаходить своє підтвердження в літературних джерелах (Khan and Samiullah, 1998; Povh and Ono 2006; Fauate et al., 2007). Проведені нами дослідження свідчать, що усі три стимулятори росту зумовлювали зростання площі листкової поверхні дослідних рослин. Найбільша площа листя спостерігалася в рослин, що зазнали дії 6-бензиламінопурину. Такі зміни кількісних показників листкового апарату рослин картоплі можуть позитивно впливати на їх фотосинтетичну активність (Khan and Samiullah, 1998; Komarova, 1998; Malinauskaite and Jakiené, 2005).

Значний вплив на функцію фотосинтезу листкової пластинки мають показники іï мезоструктурної організації. Отримані нами результати вивчення елементів ме- 
зоструктури свідчать, що за дії гіберелової та 1-нафтилоцтової кислот суттєво зростала товщина основної фотосинтезувальної тканини листків - хлоренхіми. Одночасно за дії цих самих препаратів зростав об'єм клітин найактивнішої частини мезофілу - стовпчастої асиміляційної паренхіми.
Важливим показником потужності фотосинтетичного апарату є листковий індекс. Застосування всіх трьох стимуляторів росту зумовлювало його зростання. Найвище значення даного показника зафіксовано після застосування 6-бензиламінопурину за рахунок суттєвого зростання площі листя (табл.).

Табличя

Морфофізіологічна характеристика рослин картоплі сорту Санте за дії стимуляторів росту (фаза дозрівання бульб, середні дані за 2013 та 2014 роки, $n=20$ )

\begin{tabular}{|l|c|c|c|c|}
\hline \multicolumn{1}{|c|}{ Показник } & Контроль & $\begin{array}{c}\text { Гіберелова } \\
\text { кислота }\end{array}$ & $\begin{array}{c}\text { 1-Нафтилоцтова } \\
\text { кислота }\end{array}$ & $\begin{array}{c}\text { 6-Бензил- } \\
\text { амінопурин }\end{array}$ \\
\hline Висота рослини, см & $56,0 \pm 2,78$ & $67,3 \pm 3,32^{*}$ & $57,6 \pm 2,73$ & $53,5 \pm 2,61$ \\
\hline Маса сирої речовини рослини, г & $501 \pm 24,5$ & $672 \pm 33,1^{*}$ & $587 \pm 28,2$ & $585 \pm 29,1$ \\
\hline Маса сухої речовини рослини, г & $105 \pm 5,0$ & $174 \pm 8,3^{*}$ & $125 \pm 6,1$ & $116 \pm 5,7$ \\
\hline Кількість листків на рослині, шт. & $21,2 \pm 1,02$ & $27,8 \pm 1,32^{*}$ & $23,0 \pm 1,12$ & $26,3 \pm 1,28^{*}$ \\
\hline Маса сирої речовини листків, г & $53,6 \pm 2,32$ & $84,9 \pm 4,11^{*}$ & $61,9 \pm 3,23$ & $73,3 \pm 3,47^{*}$ \\
\hline Маса сухої речовини листків, г & $14,0 \pm 0,66$ & $19,0 \pm 0,83^{*}$ & $15,8 \pm 0,67$ & $16,9 \pm 0,89^{*}$ \\
\hline Площа листків, см ${ }^{2}$ & $2747 \pm 136$ & $3584 \pm 178^{*}$ & $3383 \pm 169^{*}$ & $4594 \pm 222^{*}$ \\
\hline Товщина хлоренхіми, мкм & $165 \pm 4,7$ & $289 \pm 9,4^{*}$ & $218 \pm 4,7^{*}$ & $168 \pm 3,0$ \\
\hline Об'єм клітин стовпчастої паренхіми, мкм ${ }^{3}$ & $10097 \pm 438$ & $22241 \pm 1082^{*}$ & $18077 \pm 903^{*}$ & $11716 \pm 571$ \\
\hline Товщина хлорофілоносної тканини стебла, мкм & $41,1 \pm 1,13$ & $36,1 \pm 1,16^{*}$ & $35,6 \pm 0,79^{*}$ & $46,1 \pm 1,07^{*}$ \\
\hline Листковий індекс, м/м ${ }^{2}$ & $1,31 \pm 0,073$ & $1,72 \pm 0,084^{*}$ & $1,63 \pm 0,071^{*}$ & $2,19 \pm 0,090^{*}$ \\
\hline Питома поверхнева щільність листка, мг/см ${ }^{2}$ & $3,36 \pm 0,187$ & $3,91 \pm 0,191^{*}$ & $3,51 \pm 0,176$ & $3,49 \pm 0,155$ \\
\hline Вміст суми хлорофілів (а+b), \% на сиру речовину & $0,521 \pm 0,021$ & $0,463 \pm 0,022^{*}$ & $0,542 \pm 0,024$ & $0,685 \pm 0,032^{*}$ \\
\hline Середній урожай бульб, ц/га & $144 \pm 7,2$ & $201 \pm 10,0^{*}$ & $173 \pm 8,4^{*}$ & $192 \pm 9,2^{*}$ \\
\hline
\end{tabular}

Примітка: * - різниця достовірна за $\mathrm{P}<0,05$.

Кількісна характеристика концентрації структурних елементів, які беруть участь у фотосинтетичних процессах, - це питома поверхнева щільність листка. Нами зафіксовано збільшення цього показника після обробки гібереловою кислотою внаслідок потовщення основної фотосинтезувальної тканини листка - хлоренхіми. Відомо, що у рослин картоплі фотосинтез відбувається не лише в листках, а й у стеблах за рахунок розвитку у первинній корі хлорофілоносної тканини. Результати мікроскопічних досліджень стебла свідчать, що гіберелова та 1-нафтилоцтова кислоти достовірно зменшували, а 6-бензиламінопурин збільшував товщину хлорофілоносного шару стебла.

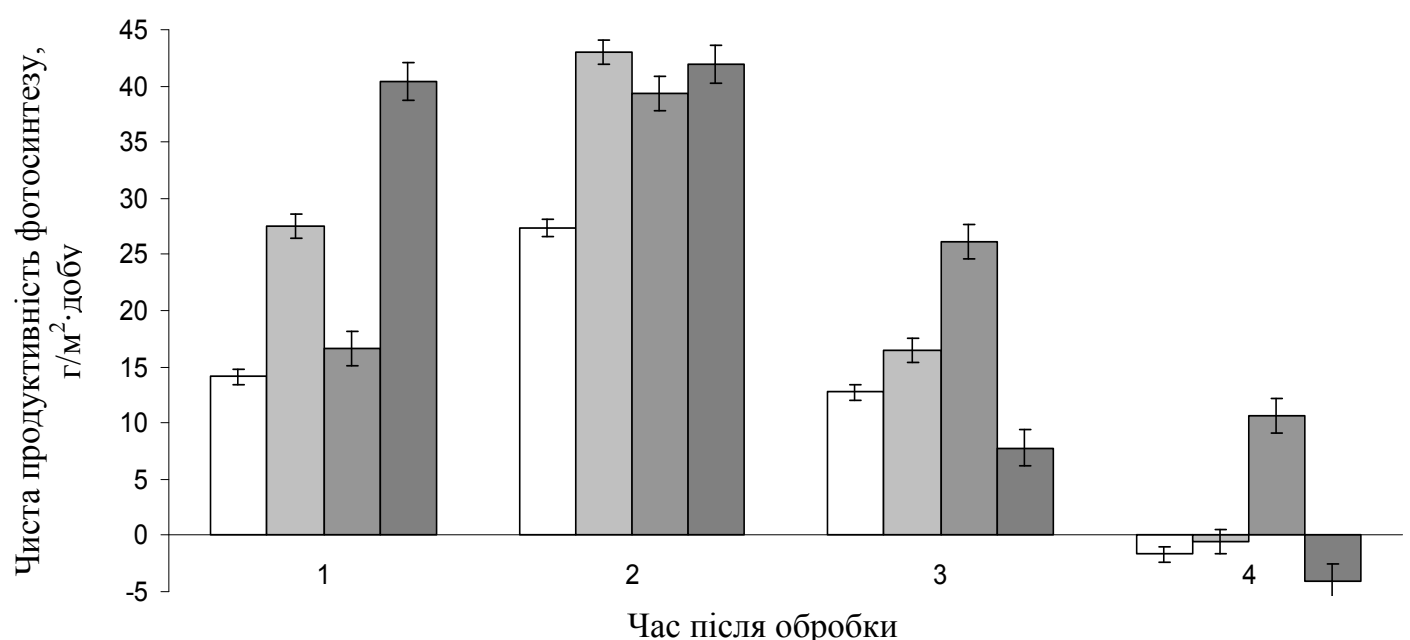

Рис. Вплив стимуляторів росту на чисту продуктивність фотосинтезу рослин картоплі сорту Санте (середні дані за 2013 і 2014 роки): час після обробки 1 - 1-10-та, 2 - 10-20-та, 3 - 20-30-та, 4 - 30-40-ва доба;

$\square$ - контроль; $\square$ - гіберелова кислота;

Морфофізіологічна активність листкового апарату також суттєво залежить від умісту хлорофілів. За результатами наших досліджень установлено, що синтетичні аналоги нативних гормонів-стимуляторів по-різному впливали на вміст основного фотосинтезувального пігменту рослин у тканинах листка. За дії 6-бензиламінопурину 1-нафтилоцтова кислота;

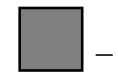

- 6-бензиламінопурин

відбувалося зростання вмісту суми хлорофілів у листках картоплі практично на третину порівняно 3 контролем (Angela, 2004). У випадку застосування гіберелової кислоти вміст хлорофілів зменшувався на 12\%, а 1-нафтилоцтова кислота практично не змінювала його концентрації. 
Отримані результати дослідження вказують на те, що зміни фітометричних і мезоструктурних показників листків та збільшення вмісту хлорофілів за впливу стимуляторів росту сприяли посиленню фотосинтетичної активності листкового апарату (рис.), свідченням чого є суттєво вищі значення чистої продуктивності фотосинтезу.

Таким чином, застосування стимуляторів росту збільшувало кількість листків, їх сиру масу та площу листя, а 6-бензиламінопурин збільшував концентрацію хлорофілу в листках. Такі зміни листкового апарату стали передумовою поліпшення продуктивності культури. У середньому по роках дослідження урожайність картоплі сорту Санте за дії гіберелової кислоти збільшувалася на 39\%, застосування 6-бензиламінопурину викликало зростання урожайності на 33\%, 1-нафтилоцтової кислоти - на 20\%.

\section{Висновки}

Синтетичні стимулятори росту та розвитку рослин 1-нафтилоцтова кислота, гіберелова кислота та 6-бензиламінопурин зумовлювали зміни морфогенезу та продуктивності рослин картоплі сорту Санте.

Гіберелова кислота збільшувала лінійні розміри дослідних рослин, масу сирої та сухої речовини цілої рослини. За дії інших препаратів вказані показники достовірно не змінювалися.

Гіберелова кислота та 6-бензиламінопурин достовірно збільшували кількість листків на рослині, масу сухої та сирої речовини листків, а всі три стимулятори росту збільшували площу листкової поверхні.

Обробка 1-нафтилоцтовою та гібереловою кислотами зумовлювала розростання хлоренхіми та збільшення об’єму клітин стовпчастої паренхіми. Вміст хлорофілу в листках достовірно зростав після обробки 6-бензиламінопурином.

Застосування всіх стимуляторів підвищувало листковий індекс та чисту продуктивність фотосинтезу, що в кінцевому результаті підвищувало урожайність культури картоплі. Найефективнішим виявилося застосування гіберелової кислоти.

\section{Бібліографічні посилання}

Angela, C., 2004. Dyphenylurea derivatives: Structure-activity relationship in plants. Acta Natur. Aten.-Parm. 40(3-4), 85-89.

Bala, M., Gupta, S., Gupta, N.K., Sangha, M.K., 2013. Practicals in plant physiology and biochemistry. Scientific, Jodhpur.
Bobyliov, Y.P., Brygadyrenko, V.V., Bulakhov, V.L., Gaichenko, V.A., Gasso, V.Y., Didukh, Y.P., Ivashov, A.V., Kucheriavyi, V.P., Maliovanyi, M.S., Mytsyk, L.P., Pakhomov, O.Y., Tsaryk, I.V., Shabanov, D.A., 2014. Ekologija [Ecology]. Folio, Kharkiv (in Ukrainian).

Fauate, A., Fauate, M., Ayub, R.A., Barbosa, M.M., 2007. Aplicacão de GA4,7+BA (promalina) afetando o crescimento, desenvolvimento e qualidade do caqui (Diospyros kaki L.) cv. Fuyu. Rev. Ceres. 54, 226-250.

Gavelienė, V., Novicienė, L., Kazlauskienè, D., 2007. Effect of auxin physiological analogues on rape growth and reproductive development. Bot. Lithuan. 13(2), 101-107.

Henselová, M., Vizárová, G., Macháčková, I., 2001. The effect of growth regulator Rastim $39 \mathrm{DKV}$ on the level of endogenous phytohormones in tomato (Solanum lycopersicum L.). Rostlinná Výroba 47(9), 411-417.

Karkar, C., Mandavia, M.K., Mandavia, C., 2007. Influence of salicylic acid and brassinolide on quality and yield of groundnut kernels. Indian Journal of Agricultural Biochemistry 20(1), 1-5.

Khan, N.A., Ansari Samiullah, H.R., 1998. Effect of gibberellic acid spray during ontogeny of mustard on growth, nutrient uptake and yield characteristics. J. Agron. Crop Sci. 181(1), 61-63.

Komarova, V., 1998. The influence of growth regulator crossing on young apple trees photosynthesis activity under soil drought: Abstr. 11th Congress of the Federation of European Societies of Plant Physiology, Varna, 7-11 Sept. Bulg. J. Plant Physiol. Spec. issue. 308.

Laichicxi, M., Mercea, M., Gheorghe, I., Grozav, M., Neamtiu, I., Dorosencu, M., Foarce, A., 2002. Preliminary research on the bioactive effect of 2-hidroyethyldimethylammonium-4aminobenzoate. Proc. Rom. Acad. 4(3), 177-179.

Malinauskaitè, R., Jakienė, E., 2005. BSB grupès stilitų įtaka raudonžiedžio šalavijo augimui. Vagos $67,25-30$.

Povh, J.A., Ono, E.O., 2006. Rendimento de oleo essensial de Salvia officinalis L. sob acbao de reguladores vegetais. Acta Sci., Biol. Sci. 28(3), 189-193.

Romaniuk, N., Troyan, V., Musiyaka, V., Bezveniuk, Z., Terek, O., 1998. Growth-regulating activity of emistym, the new perspective plant growth regulator: Abstr. 11th Congress of the Federation of European Societies of Plant Physiology, Varna, 7-11 Sept. Bulg. J. Plant Physiol. Spec. issue. 309.

Van Emden, H.F., 2008. Statistics for terrified biologists. Blackwell, Oxford.

Xinping, C., Hongyu, Y., Rongzhi, C., Lili, Z., Bo, D., Qingmei, W., Guangeun, H., 2002. Isolation and characterization of triacontanolregulated genes in rice (Oryza sativa L.): Possible role of triacontanol as a plant growth stimulator. Plant Cell Physiol. 43(8), 869-876.

Zrůst, J., Henselová, M., 1998. Vliv benzolinonu na tvorbu bramborových hlíz. Rostl. Vyroba 44(12), 533-538.

Надійшла до редколегії 12.09.2015 